\title{
PENGARUH SELF-EFFICACY DAN MOTIVASI BELAJAR TERHADAP KEMANDIRIAN BELAJAR MATEMATIKA
}

\author{
Nurul Laili \\ MI Mubammadiyah Program Khusus Boyolali, Indonesia \\ Email: laillaili1998@gmail.com
}

\begin{abstract}
The study aims to investigate: 1) The effect of self-efficacy on the independene learning of mathematics; 2) The effect of learning motivation on the independene learning of mathematics; 3) The effect of self-efficacy and learning motivation as an aggregate on the independene learning of mathematics. This type of research is a quantitative with an approach ex-post facto. The population in this research is eight grade students of SMP Negeri 1 Musuk. Sampling was done by using purposive sampling is class VIII G SMP Negeri 1 Musuk. The data were collected through a questionnaire and documentation. The hypothesis testing used simple regression analysis and multiple regression analysis. The results of the study are as follows. 1) There is a positive effect and significant of self-efficacy on the independene learning of mathematics, indicated by a correlation coefficient value of 0.770 , a determination coefficient value 0,593 and $t_{\text {value }}>t_{\text {table }}$ of $(6,606>2,042)$; 2) There is a positive effect and significant of learning motivation on the independene learning of mathematics, indicated by a correlation coefficient value of 0,852 , a determination coefficient value 0,727 and $t_{\text {value }}>t_{\text {table }}$ of $\left.(8,928>2,042) ; 3\right)$ There is a positive effect and significant of self-efficacy and learning motivation on the independene learning of mathematics, indicated by a correlation coefficient value of 0,873 , a determination coefficient value 0,762 and $F_{\text {value }}>F_{\text {table }}$ of $(8,928>2,042)$.
\end{abstract}

Keywords: self-efficacy, learning motivation, independent learning

\begin{abstract}
Abstrak
Penelitian bertujuan untuk mengetahui: 1) Pengaruh self-efficacy terhadap kemandirian belajar matematika; 2) Pengaruh motivasi belajar terhadap kemandirian belajar matematika; 3)Pengaruh selfefficacy dan motivasi belajar secara bersama-sama terhadap kemandirian belajar matematika. Jenis penelitian ini adalah penelitian kuantitatif dengan pendekatan ex-post facto. Populasi dalam penelitian ini adalah peserta didik kelas VIII SMP Negeri 1 Musuk. Pengambilan sampel dalam penelitian ini dilakukan secara purposive sampling yaitu kelas VIII G SMP Negeri 1 Musuk. Teknik pengumpulan data menggunakan angket, dan dokumentasi. Pengujian hipotesis penelitian menggunakan analisis regresi sederhana dan analisis regresi berganda. Hasil Penelitian menunjukkan bahwa: 1) Terdapat pengaruh positif dan signifikan self-efficacy terhadap kemandirian belajar Matematika dibuktikan dengan nilai koefisien korelasi sebesar 0,770, nilai koefisien determinasi 0,593 dan nilai $t_{\text {hitung }}>\mathrm{t}_{\text {tabel }}(6,606>2,042)$; 2) Terdapat pengaruh positif dan signifikan motivasi belajar terhadap kemandirian belajar Matematika dibuktikan dengan nilai koefisien korelasi sebesar 0,852 , nilai koefisien determinasi 0,727 dan nilai $\left.t_{\text {hitung }}>t_{\text {tabel }}(8,928>2,042) ; 3\right)$ Terdapat pengaruh positif dan signifikan self-efficacy dan motivasi belajar secara bersama-sama terhadap kemandirian belajar Matematika dibuktikan dengan nilai koefisien korelasi sebesar 0,873, nilai koefisien determinasi 0,762 dan nilai $F_{\text {hitung }}>F_{\text {tabel }}(46,382>3,32)$.
\end{abstract}

Kata Kunci: Self-Efficacy, Motivasi Belajar, Kemandirian Belajar 


\section{PENDAHULUAN}

Matematika merupakan suatu mata pelajaran yang diberikan pada setiap jenjang pendidikan di sekolah, dari mulai pendidikan dasar sampai dengan perguruan tinggi. Matematika tidak hanya menjadi suatu mata pelajaran yang dijumpai di sekolah, namun juga memiliki peranan yang penting dalam kehidupan sehari-hari. Seperti yang dikemukakan Sari (dalam Ruswati dkk, 2018:92) bahwa matematika merupakan bagian dari pendidikan yang tidak bisa dipisahkan dari kehidupan manusia. Menyadari begitu pentingnya ilmu matematika, seharusnya menjadikan matematika sebagai kebutuhan bagi peserta didik dan menjadikannya suatu mata pelajaran yang menyenangkan.

Pada kenyataannya matematika masih menjadi mata pelajaran yang menakutkan, sehingga beberapa peserta didik yang akan memasuki pelajaran matematika akan merasa kurang semangat dan malas. Ketakutan yang dialami oleh peserta didik tersebut akan berdampak terhadap kurangnya pemahaman matematika. Rendahnya kemampuan matematika di Indonesia ini dapat dilihat dari hasil survei PISA 2018 menempatkan Indonesia ada diperingkat ke-7 dari bawah dengan skor 379 (OECD, 2018:18).

Banyak hal sederhana yang menjadi faktor keberhasilan dalam matematika namun kurang diperhatikan oleh peserta didik, salah satunya adalah kemandirian belajar. Kemandirian belajar adalah kemampuan seseorang dalam mengatur semua aktivitas pribadi, kompetensi, dan kecakapan secara mandiri berbekal kemampuan dasar yang dimiliki individu tersebut, khususnya dalam proses pembelajaran (Ningsih \& Nurrahmah, 2016:76). Hal ini menunjukkan bahwa dengan kemandirian belajar, seseorang dapat mengontrol tindakannya sendiri, bebas dalam mengatur aktivitas dan kompetensi serta kecakapan yang akan dicapainya.

Menurut Basri (dalam Nugrahani, 2013:15) terdapat dua faktor yang mempengaruhi kemandirian belajar yaitu faktor dari dalam diri peserta didik (faktor endogen) dan faktor dari luar diri peserta didik (faktor eksogen). Faktor dari dalam diri peserta didik (faktor endogen) meliputi motivasi belajar, bakat, minat, self-efficacy, dan kebiasaan belajar. Faktor dari luar diri peserta didik (faktor eksogen) meliputi metode mengajar, kurikulum, faktor lingkungan alam, sarana dan prasarana. Dalam penelitian ini peneliti membatasi faktor kemandirian belajar lebih pada faktor internal yaitu self-efficacy dan motivasi belajar.

Bandura (dalam Fitriani, 2017:142) mendefinisikan self-effiacy sebagai keyakinan individu mengenai kemampuan dirinya dalam melakukan tugas atau tindakan yang dilakukan dalam mencapai tujuan tertentu. Diperlukannya self-efficacy ini untuk meningkatkan kepercayaan peserta didik dalam menghadapi masalah yang muncul, seperti menyelesaikan tugas yang diberikan oleh pendidik, menyelesaikan soal-soal yang sulit, pemenuhan target nilai (KKM), dan lain sebagainya.

Selain self-efficacy faktor lain yang mempengaruhi kemandirian belajar adalah motivasi belajar. Motivasi belajar merupakan dorongan semangat yang terdapat dalam diri seseorang untuk melakukan aktivitas belajar dengan baik dalam mencapai hasil yang maksimal. Peserta didik akan berhasil dalam proses belajar apabila ada dorongan dari diri sendiri atau kata lain adalah motivasi belajar (Ma'shumah \& Muhsin, 2019: 320). Dengan adanya motivasi, siswa akan belajar lebih keras, ulet, tekun dan memiliki konsentrasi penuh dalam proses belajar pembelajaran. Hal ini menunjukkan bahwa dorongan motivasi dalam belajar merupakan salah satu hal yang perlu dibangkitkan dalam upaya pembelajaran. Tanpa adanya self-efficacy dan motivasi belajar, peserta didik tidak akan bergairah dalam menyerap materi.

Berdasarkan hasil observasi di SMP Negeri 1 Musuk bahwa kemandirian belajar matematika pada peserta didik masih rendah. Hal ini dibuktikan berdasarkan observasi yang telah dilakukan kepada 32 peserta didik dimana terdapat 37,5\% peserta didik masih meminta pertolongan jawaban 
kepada kelompok lain, 28,12\% peserta didik tidak aktif dalam diskusi, dan 34,38\% peserta didik aktif dalam berdiskusi.

Dalam pengerjaan tugas kelompok tersebut terdapat peserta didik yang tidak ikut mengerjakan dan hanya mengandalkan teman satu kelompoknya yang dianggap pintar. Permasalahan lain yang terlihat yaitu kurangnya rasa percaya diri peserta didik ketika mengerjakan soal. Hal ini dibuktikan saat peserta didik mengerjakan soal secara kelompok kemudian dicocokan dengan jawaban kelompok lain maka akan terjadi kesesuaian yaitu jika jawaban yang diperoleh tidak sama, peserta didik cenderung akan mengganti jawaban dengan jawaban yang benar seperti kelompok lain.

Berdasarkan hal-hal tersebut sehingga peneliti bermaksud untuk mengetahui secara pasti dan jelas, melalui prosedural ilmiah dengan mengangkat judul "Pengaruh Self-efficacy dan Motivasi Belajar terhadap Kemandirian Belajar Matematika pada Peserta Didik Kelas VIII SMP Negeri 1 Musuk Tahun Pelajaran 2020/2021”.

Berdasarkan latar belakang masalah yang telah diuraikan di atas, maka secara ringkas masalah dalam penelitian ini dapat dirumuskan sebagai berikut:

1. Bagaimanakah pengaruh self-efficacy terhadap kemandirian belajar matematika pada peserta didik kelas VIII SMP Negeri 1 Musuk?

2. Bagaimanakah pengaruh motivasi belajar terhadap kemandirian belajar matematika pada peserta didik kelas VIII SMP Negeri 1 Musuk?

3. Bagaimanakah pengaruh self-efficacy dan motivasi belajar terhadap kemandirian belajar matematika pada peserta didik kelas VIII SMP Negeri 1 Musuk?

Berdasarkan rumusan masalah yang telah diuraikan di atas, tujuan yang ingin dicapai dari penelitian ini sebagai berikut:

1. Mengetahui pengaruh self-efficacy terhadap kemandirian belajar matematika pada peserta didik kelas VIII SMP Negeri 1 Musuk.

2. Mengetahui pengaruh motivasi belajar terhadap kemandirian belajar matematika pada peserta didik kelas VIII SMP Negeri 1 Musuk.

3. Mengetahui pengaruh self-efficacy dan motivasi belajar terhadap kemandirian belajar matematika pada peserta didik kelas VIII SMP Negeri 1 Musuk.

\section{METODE}

Penelitian ini merupakan penelitian kuantitatif, dengan pendekatan ex-post facto. Penelitian ini bersifat asosiatif kausal dengan tujuan untuk mengetahui pengaruh dua variabel bebas atau lebih terhadap variabel terikat. Penelitian ini dilaksanakan di SMP Negeri 1 Musuk pada tanggal 2 Oktober 2020 sampai tanggal 15 November 2020.

Subjek penelitian ini adalah seluruh siswa kelas VIII SMP Negeri 1 Musuk tahun pelajaran 2020/ 2021 yang terdiri dari tujuh kelas dengan jumlah 224 siswa. Penelitian ini menggunakan metode nonprobability sampling dengan teknik pengambilan sampel yang digunakan purposive sampling yaitu siswa kelas VIII-G sebagai sampel penelitian.

Penelitian diawali dengan penjabaran latar belakang masalah. kemudian dari latar belakang dilakukan identifikasi masalah, dilanjutkan menentukan rumusan masalah. Setelah dilakukan perumusan masalah maka dibuat hipotesis atas rumusan masalah yang didasarkan pada kajian teori. Langkah selanjutnya adalah pengambilan data penelitian melalui dokumentasi dan angket mengenai selfefficacy, motivasi belajar dan kemandirian belajar matematika. Dari data yang telah terkumpul 
dilakukan analisis dan pembahasan untuk membuktikan hipotesis yang telah dirumuskan sebelumnya. Langkah terakhiri adalah menarik kesimpulan dari hasil analisa dan pembahasan.

Variabel dalam penelitian ini terdiri dari variabel bebas dan variabel terikat. Variabel bebas dalam penelitian ini, adalah self-efficacy (X1) dan motivasi belajar (X2). Sedangkan yang menjadi variabel terikat adalah kemandirian belajar matematika.

Instrumen penelitian yang digunakan dalam penelitian ini yaitu berupa angket. Angket ini digunakan untuk mengukur self-efficacy, motivasi belajar dan kemandirian belajar matematika. Metode pengumpulan data yang digunakan dalam penelitian ini adalah metode dokumentasi dan angket. Metode dokumentasi dalam penelitian ini digunakan untuk mendapatkan data nama dan jumlah peserta didik yang menjadi anggota populasi dan sampel. Data yang digunakan dalam penelitian ini adalah skor yang dihasilkan dari angket yang telah diisi oleh peserta didik untuk mengetahui self-efficacy, motivasi belajar dan kemandirian belajar. Data yang digunakan dalam penelitian diperoleh melalui angket yang telah di uji coba dengan uji validitas dan uji reliabilitas. Teknik analisis data yang digunakan adalah analisa regresi sederhana dan analisa regresi berganda dengan bantuan SPSS versi 24.0 untuk mengetahui pengaruh variabel bebas terhadap variabel terikat.

\section{HASIL DAN PEMBAHASAN}

\section{Pengaruh Self-Efficacy terhadap Kemandirian Belajar Matematika}

Tabel 1. Ringkasan Hasil Analisis Regresi Sederhana $\left(\mathrm{X}_{1}-\mathrm{Y}\right)$

\begin{tabular}{|l|l|l|l|l|l|}
\hline \multicolumn{2}{|c|}{ Variabel } & $\begin{array}{c}\text { Koef. } \\
\text { korelasi }\end{array}$ & $\begin{array}{c}\text { Koef. } \\
\text { Determinasi }\end{array}$ & thitung $^{\text {Self }}$ & \multicolumn{1}{c|}{ Sig. } \\
\hline Self-Effiacy & Kemandirian belajar matematika & 0,770 & 0,593 & 6,606 & 0,000 \\
\hline
\end{tabular}

Hasil penelitian menunjukkan koefisien korelasi $\mathrm{rx}_{1} \mathrm{y}$ sebesar 0,770 dan koefisien determinasi $r^{2} x_{1} y$ sebesar 0,593 yang memiliki arti bahwa terdapat pengaruh positif Self-Efficacy terhadap Kemandirian Belajar Matematika pada peserta didik kelas VIII SMP Negeri 1 Musuk Tahun Pelajaran 2020/2021 sebesar 59,3\% dan sisanya (40,7\%) dipengaruhi oleh faktor lain. Uji t yang dilakukan menunjukkan bahwa $t_{\text {hitung }} 6,606$ lebih besar dari $t_{\text {tabel }}$ pada taraf signifikansi $5 \%$ dan $d f 30$ sebesar 2,042 sehingga pengaruh Self-Efficacy terhadap Kemandirian Belajar Matematika adalah signifikan. Kesimpulan dari analisis ini adalah terdapat pengaruh positif dan signifikan Self-Efficacy terhadap Kemandirian Belajar Matematika pada peserta didik kelas VIII SMP Negeri 1 Musuk tahun pelajaran 2020/2021

\section{Pengaruh Motivasi Belajar terhadap Kemandirian Belajar Matematika}

Tabel 2. Ringkasan Hasil Analisis Regresi Sederhana $\left(\mathrm{X}_{2}-\mathrm{Y}\right)$

\begin{tabular}{|c|c|c|c|c|c|}
\hline & Variabel & Koef. korelasi & $\begin{array}{l}\text { Koef. } \\
\text { Dete }\end{array}$ & $\mathrm{t}_{\text {hitun }}$ & Sig. \\
\hline Motivasi belajar & Kemandirian belajar matematika & 0,852 & 0,727 & $\begin{array}{l}8,92 \\
8\end{array}$ & $\begin{array}{l}0,00 \\
0\end{array}$ \\
\hline
\end{tabular}

Hasil penelitian menunjukkan koefisien korelasi sebesar 0,852 dan koefisien determinasi sebesar 0,727 yang memiliki arti bahwa terdapat pengaruh positif Motivasi Belajar terhadap 
Kemandirian Belajar Matematika pada peserta didik kelas VIII SMP Negeri 1 Musuk Tahun Pelajaran 2020/2021 sebesar 72,7\% dan sisanya (27,3\%) dipengaruhi oleh faktor lain. Uji t yang dilakukan menunjukkan bahwa thitung 8,928 lebih besar dari tabel pada taraf signifikansi $5 \%$ dan df 30 sebesar 2,042 sehingga pengaruh Motivasi Belajar terhadap Kemandirian Belajar Matematika adalah signifikan. Kesimpulan dari analisis ini adalah terdapat pengaruh positif dan signifikan Motivasi Belajar terhadap Kemandirian Belajar Matematika pada peserta didik kelas VIII SMP Negeri 1 Musuk tahun pelajaran 2020/2021.

\section{Pengaruh Self-Efficacy dan Motivasi Belajar secara Bersama-sama terhadap Kemandirian Belajar Matematika}

Tabel 3. Ringkasan Hasil Analisis Regresi Berganda $\left(\mathrm{X}_{1}\right.$ dan $\left.\mathrm{X}_{2}-\mathrm{Y}\right)$

\begin{tabular}{|l|l|l|l|l|}
\hline \multicolumn{2}{|c|}{ Variabel } & Koef. & $\mathrm{F}_{\text {hitung }}$ & Sig. \\
\cline { 1 - 4 } Self-Efficacy & Kemandirian Belajar Matematika & 0,873 & 46,382 & 0,000 \\
\cline { 1 - 2 } Motivasi Belajar & & & & \\
\hline $\mathrm{R}$ & 0,873 & 0,762 & & \\
\hline $\mathrm{R}^{2}$ &
\end{tabular}

Hasil pengujian regresi berganda menunjukkan bahwa nilai koefisien korelasi $R_{y}(1,2)$ sebesar 0,873 dan koefisien determinasi $\mathrm{R}^{2} \mathrm{y}(1,2)$ sebesar 0,762 yang memiliki arti bahwa terdapat pengaruh positif Self-Efficacy dan Motivasi Belajar secara bersama-sama terhadap Kemandirian Belajar Matemaatika pada Peserta Didik Kelas VIII SMP Negeri 1 Musuk Tahun Pelajaran 2020/2021 sebesar 76,2 \% dan sisanya (23,8\%) dipengaruhi oleh faktor lain.Uji $F$ yang dilakukan menunjukkan bahwa Fhitung 46,382 lebih besar dari Ftabel pada taraf signifikansi 5\% dan df 2;30 sebesar 3,32 sehingga pengaruh Self- Efficacy, dan Motivasi Belajar secara bersama-sama terhadap Kemandirian Belajar Matematika adalah signifikan. Kesimpulan dari analisis ini adalah terdapat pengaruh positif dan signifikan Self-Efficacy, dan Motivasi Belajar secara bersama-sama terhadap Kemandirian Belajar Matematika pada peserta didik kelas VIII SMP Negeri 1 Musuk tahun pelajaran 2020/2021.

\section{SIMPULAN}

Bersadarkan hasil penelitian dan pembahasan yang diperoleh dari analisis data yang dilakukan, maka dapat ditarik kesimpulan bahwa :

1. Terdapat pengaruh positif dan signifikan Self-Efficacy terhadap Kemandirian Belajar Matematika pada peserta didik kelas VIII SMP Negeri 1 Musuk tahun pelajaran 2020/2021 dengan koefisien korelasi sebesar 0,770; koefisien determinasi sebesar 0,593; dan thitung 6,606 lebih besar dari tabel sebesar 2,042.

2. Terdapat pengaruh positif dan signifikan Motivasi Belajar terhadap Kemandirian Belajar Matematika pada peserta didik kelas VIII SMP Negeri 1 Musuk tahun pelajaran 2020/2021 dengan koefisien korelasi sebesar 0,852 koefisien determinasi sebesar 0,727; dan $t_{\text {hitung }} 8,928$ lebih besar dari $\mathrm{t}_{\text {tabel }}$ sebesar 2,042.

3. Terdapat pengaruh positif dan signifikan Self-Efficacy, dan Motivasi Belajar secara bersamasama terhadap Kemandirian Belajar Matematika pada peserta didik kelas VIII SMP Negeri 1 Musuk tahun pelajaran 2020/2021 dengan koefisien korelasi Ry(1,2) sebesar 0,873; koefisien determinasi $\mathrm{R}^{2} \mathrm{y}(1,2)$ sebesar 0,762 ; dan $\mathrm{F}_{\text {hitung }} 46,382$ lebih besar dari $\mathrm{F}_{\text {tabel }}$ sebesar 3,32. 


\section{DAFTAR PUSTAKA}

Fitriani, W. (2017). Analisis Self-Efficacy Dan Hasil Belajar Matematika Siswa Di Man 2 Batusangkar Berdasarkan Gender. Agenda, 1(1), 141-158.

Ma'shumah, F., \& Muhsin. (2019). Pengaruh Motivasi Belajar, Disiplin Belajar, Cara Belajar Dan Interaksi Teman Sebaya Terbadap Kesiapan Belajar. 8(1), 318-332.

Ningsih, R., \& Nurrahmah, A. (2016). Pengaruh Kemandirian Belajar dan Perhatian Orang Tua Terhadap Prestasi Belajar Matematika. Formatif: Jurnal Ilmiah Pendidikan MIP A, 6(1), 73-84.

Nugrahani, R. (2013). Hubungan Self-Efficacy dan Motivasi Belajar dengan Kemandirian Belajar Siswa Kelas V SD Negeri Se-Kecamatan Danurejan Yogyakarta.Skripsi S1.Fakultas Ilmu Pendidikan, Univertitas Negeri Yogyakarta.

OECD. (2018). PIS A 2018 results. I. https://www.oecd.org/pisa/publications/PISA2018_CN_BRA.pdf

Ruswati, D., Utami, W. T., \& Senjayawati, E. (2018). Analisis Kesalahan Siswa SMP dalam menyelesaikan soal kemampuan pemecahan masalah matematis ditinjau dari tiga aspek. Maju, 5(1), 91-107. 